\title{
集落地域整備計画策定における阻害要因に関する考察 OBSTRUCTIVE FACTOR ON PLANNING PROCESS OF VILLAGE-AREA ADJUSTMENT
}

\author{
鎌田元 弘*, 土肥 博至**, 坂 本 淳二*** \\ Motohiro KAMATA, Hiroshi DOHI and Junji SAKAMOTO
}

\begin{abstract}
Many muacipalltles are maklag plan on "Village-area Adjustment Act". In this paper, We Intend to establish the index of obstructive factor on the planing process in villagearea. We sent out queslionaires about planing process to municipal administrators. By the analysis ofthis dala, We expected to extract the obstructive factor.

The made next 3 study-frame to clear the problem.

Framel:Necesslly of planning on inhabitanl side and admloistration side. frame 2 : The complicallon of communlty and plaoning condilion.

Frame3:The regulation of the inhabilant side and administration side on planning process. Considering the frame, We concluded that coexisting type, commyulty type and muragara is elfectlve to foresee the obstructive factor.
\end{abstract}

Keywords: VIllage-area Adjusiment Acl, planolog Drocess, obstructive factor

集落地域整储法, 計画プロセス，阻害要因

\section{1、研究の背䍗}

農村整備の画期的な法律として登場した集落地域整備 法（以下、集整法と呼ぶ）も制定後 7 年を経過し、北海 道から沖耗まで全国の地域でこの法律に基つく調査が行 なわれてきた。しかし、実際に事業化に向けて動きだし たケースは僅か数例のみである。このような背景には、 生活空間と生産空間の重なり、社会性と空間性の重なり といった個々の集落の特殊事情もあろうが、集落を法体 系にそって全体的・計面的に整借していくということ自 体が集落にとっては未絓験なことであり、それが最大の ネックになっていると言えよう。また、農水省と建設省 の共管という法律のユニークさが、そのまま欠点にもな っていることも否定できない。また、集整法に関する調 查の実施状況についてみると、同一集落で集落農振計画 または集落地区計画の両方を実施したのは、全体の 27 \%にすぎず拑1、法律本来のバランスのとれた計画策定 という主旨から考えると、必ずしも期待通りの展開を示
しているとは言えない。 次にいくつかの先行研究から、集落整偏計画の手順お よび集整法の問題点について整理する。

三国らは、市街化調整区域の場合は、規制瑷和の一面 を持つのに対して、未線引都市計画区域の場合は一方的 な規制強化の面が強いため土地所有者の合意が得にくい こと刘）ままた、計画策定ブロセスにおいて、住民の種 々の㸴から意見を吸い上げるような複合的組織構成をと る必要があることを指摘している林2)。系長らは、調整 区域の人口停滞・減少地域における集落活性化方策とし ての集整法適用の問題に言及している*文了)。川鸠は、農 家の農地利用意向から経営パターン別に整僻課題を整理 している划)。弥吉らは、集落地域整備の実施例から、 集整法の制度の中で都市・農政両サイドの調整が行なか れたのは、県レベルで基本方針を策定する段階だけであ

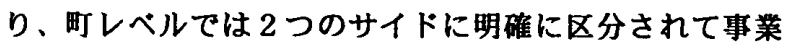
化が行なわれていることが報告されている゙柌。
* 千葉工業大学建築学科 講師・学博

** 筑波大学芸術学系 教授. 工博

*** 筑波大学環境科学研究科 技官(淮研究員). 学修
Lecture, Chiba Institute of Technology, Ph. D.

Prof., Tsukuba Univ., Dr. Eng.

Researcher, Tsukuba Univ., Ph. M. 
日本建策学会農村計画委員会中竘)では、集整法の基本 方針の策定を目的として、「姆地優位・水田偍位の区分」 と「都市化傾向や宅地化傾向の大小の区分」の組合せに よる集落類型の抽出、およびそれらの市町村レベルでの 位置付けを行なっている。いずれも計画条件を整理する 上で有效な指標と考えられるが、計画の推進といった視 点から整理されているものではない。秋山*文》は、(1)計 画策定過程における諸問題。特に集整法適用の妥当性、 (2)農村集落独自の計画技術の課題。(3)新規宅地の創出の 諸閭題。特に位䁂・规模・創出方法等。(4)調查の推進。 等の問題点を指摘している。いずれも、実際の計画の現 場として発生し得る問題を整理している。

以上、先進研究を概観したが、地城特性に応じた計画 策定上の合意形成の問題点、行政レベルでの担当間の調 整、集落類型別の整備課題の抽出等の問題について報告 されてはいるものの、いずれも事例的報告の即陼であり、 集落整備計画を策定する上での阻害要因に関する体系的 な考察は、十分になされているとは言えない。

\section{2. 研究の目的と方法}

計画策定を行なう上で阻害となる要因は、相互に椱雜 に絡み合い、その解決自体が計画を特徽づけることにな るものでもあるか、多くの場合個別的・地域的な特殊条 件として捉えられることが多く、一般化して捉えられる ことは少ない。本論では、集整法の計画策定調查事業を 分析することにより、市町村の行政担当者レベルにおけ る集落計画プロセスの阻害要因を指標的に捉え、計画の 与件として位直付けることを目的としたものである。

研究を進めるにあたって、行政担当者に対する調查を 実施した。これは行政担当者からみた地域や行政組織の 問題点や訫画策定上の評価を把握するための調查推2)で ある。調查対象は集整法の適用を目的とした調查を実施 した市町村の集落整偏の担当者（農業系の担当者、都市 - 建設系の担当者および集落整備専門の担当者）とし、 アンケートの配布および回収は、いずれも諥送により行 なった（留固期間 2 週間程度・平成 2 年度実施）。アン ケートの回收状況を表ー 1 に示す淮了。

研究は、以下のような手順で進める。 (1)研究フレームとしての阻害要因の設定。 (2)計画策定上、発生する阻害要因の内容の把握。 (3)研究フレームの検証。 (4)阻害要因を予見するための指標の検討。

\section{3、研究フレームの設定}

計画策定上の阻害要因として、基本計画の策定から事 業化に至る様々なレべル、法制度上の問題から個人に至 るまで様々な要因が考えられるが、ここでは集落地域整
表-1 アンケートの配布回収状況

\begin{tabular}{c|c|c|c|c}
\hline \multirow{2}{*}{ アンケートの配布数豊業関連 } & $\begin{array}{c}\text { 建設関連 } \\
\text { 担当 } \\
\text { 担当 }\end{array}$ & $\begin{array}{c}\text { 等分に分担 } \\
\text { または専門の担当 }\end{array}$ & 回収率 \\
\hline 55 & 17 & 10 & 17 & $80 \%$ \\
\hline
\end{tabular}

偏計面における基本計画策定の初期段陼における問題に 限定して、阻害要因を大きく住民側と行政側の 2 面から 捉え、次のような研究フレームを設定する。

・フレーム 1 : 計画がその市町村や集落地域にとって必 ずしも必要でない場合、それが計画の進行にどのよう に影皘するか。

・フレーム 2 : 集落地域にとって、計画条件が錯綜して いる状況は、計画の進行にどのように影鰵するか。

・フレーム 3 : 住民側・行政側のそれぞれで、阻害要因 の調整機能が不十分である場合、それが計画の進行に どように影鳘するか。

更に以上の分析を踏まえ、阻害要因を計画の予見とし て把握する指標として、著者らの先行研究で示した「混 住化類型 の有效性を検証する。

\section{4、阻害要因の内容}

ここでは、行政アンケート結果より阻害要因の内容に ついて検討する。

表 -2 は計画策定上の全体的な閣題点および計画策定 の発端・計画策定上のリーダーシップ・関保条例の淮 状況を示すものである。問題点についてみると、行政側 の調整や運用に関する問逐、法制度や事業化に関する問 題、住民間の合意形成や権利調整に関する問題に大別さ れる。計画策定の発端は、6 割が国や県の指導であり、 市町村の発意となったものが 3 割、住民の発意によるも のは 1 割に满たない状況である。また、計画策定上のリ ーダーシッブをとったものは、殆どが市町村の担当者で あるが、市町村における関係条例の準備状況では、半数 以上が関保した条例を発令する予定がないといった状況 である。以上から、主体となるべき地城住民の計画策定 への関わりが初期的段陼においては檽めて希薄であるこ と。また、市町村の状況を把握していると考えられる行 政担当者においては、乾画策定の発意は多くは上位官庁 の指導によるもので、条例の制定等の市町村における等 備も消極的なケースが多い。このように集落地城の計画 策定は内部からの必要性から発生したものではないにも かかわらず、市町村の担当者は、行政的な位置付け（淮 俑）も不十分な状況でその中心的段割を担っていること が伺われる枇4)。

以上から、フレーム $1 \sim 3$ の設定に意義があることが 
認められる。

\section{5、計画策定の必要性}

ここでは、フレーム1の検討を行なう。検討にあたっ ては、(1)市町村おける当該集落地域の計画策定の必要 性 (2) 当該集落地域における計画策定の必要性 の2 面から考察する。(1)に関しては「市町村レペルでの主 要整備課題」と当該集落地域における集落の性格、計画 目的、計画対象となる集落地域の選定方法、の 3 項目と の関係から判定する。(2)に関しては集落性格と計画目 的との組合せと、計画の進行状況の関係を分析すること によって判定する。

(1)市町村おける当該集落地域の計画策定の必要性

市町村の主要整備課題別の集落の性格および計画の目 的（表ー3）注5)では、「市街地周辺地域の整備」を主 要整備課題とする市町村では、スプロール集落・中心集 落などの比较的それに対応した集落が選定され、また、 それに合致した計画目的が設定されているが、既成市街 地整備を主要施策としている市町村においては、スプロ 一ル的集落が最も多いが、純農村的集落が対象となり、 生産が目的になっている例も見られる。逆に農村地域の 整備を主要施策としている市町村では、その多くが既に スプロール的集落あり、中には開発的整備を目的として いる例も見られる。

市町村における集落地域の選定については（表－4）、 既成市街地の整備を主要施策としている市町村では特定 の選定理由が見当らないこと。市街地周辺部を主要施策 としている市町村では主要施策の対象地区や調查の結果 等に特化していること。農村地域の整備を主要施策とし ている市町村では個別状況に伡って選択される場合が多 いこと等の傾向が読み取れる。

以上から、市町村によって多栐な思感が倠いているこ とが同われるが、市街地周辺部の整備を主要施策として いる市町村においては、既成市街地や農村地域の整備を 主要施策としている市町村にくらべ、計画策定の必要性 が高いように思われる。

\section{(2) 集落地域における即画策定の必要性}

表一 5 は、集落の性格、計画の目的、計画の進行状识 の3 項目による整理を行なったものである。

スプロール的集落の場合は、生産罢境整備および居住 晨境整借については、計画が進行している事例が多くみ られるが、開発的整備については、その傾向は見られな い。中心集落の場合は、計画目的は居住環境整備と開発 的整備に限定され、どちらも計画は促進されない㑯向が みられる。純農村的集落の開発的整備のように、必ずし も開発のインパクトが強いと思われない状況においては 計画は進行していない。また、純農村的地域という集落
表 -2 集落整備法の問題点

\begin{tabular}{|c|c|c|}
\hline \multirow{4}{*}{ 問題点 } & 法制度に関するもの & $14(34.1)$ \\
\hline & 行政指導に関するもの & $19(46.3)$ \\
\hline & 住民間の調整 & $8(19.5)$ \\
\hline & 合計 & 41 \\
\hline \multirow{4}{*}{ 計画の発端 } & 住民の発意 & $3(6.9)$ \\
\hline & 市町村の発意 & $14(32.5)$ \\
\hline & 国や県の指道 & $26(60.5)$ \\
\hline & 合計 & 43 \\
\hline \multirow{4}{*}{ リ-ダ -シ・gブ } & 地域住民 & $0(0.0)$ \\
\hline & コンサル・学識経験者 & $5(11.6)$ \\
\hline & 市町村の担当者 & $38(88.4)$ \\
\hline & 合計 & 43 \\
\hline \multirow{4}{*}{ 条例の準備 } & 眊令・検討中 & $15(34.8)$ \\
\hline & 発令の予定なし & $22(51.2)$ \\
\hline & 未 定 & $6(14.0)$ \\
\hline & 合計 & 43 \\
\hline
\end{tabular}

表-3 市町村の整備課題と集落の性格・計画目的

\begin{tabular}{|c|c|c|c|c|c|c|c|c|c|}
\hline & \multicolumn{3}{|c|}{ 集落性格 } & \multirow[b]{2}{*}{ 合婛 } & \multicolumn{3}{|c|}{ 計画目的 } & \multirow[b]{2}{*}{ 合計 } \\
\hline & & $27^{\circ} \square-N$ & 中心 & 蚛農村 & & $\begin{array}{l}\text { 生産 } \\
\text { 整满 }\end{array}$ & $\begin{array}{l}\text { 居住 } \\
\text { 整備 }\end{array}$ & $\begin{array}{c}\text { 開発的 } \\
\text { 整備 }\end{array}$ & \\
\hline $\begin{array}{l}\text { 主 } \\
\text { 要 }\end{array}$ & $\begin{array}{c}\text { 既成 } \\
\text { 市街地 }\end{array}$ & $\begin{array}{c}5 \\
50.0\end{array}$ & $\begin{array}{c}2 \\
20.0\end{array}$ & $\begin{array}{c}3 \\
30.0\end{array}$ & 10 & $\begin{array}{c}2 \\
18.2\end{array}$ & $\begin{array}{c}5 \\
45.5\end{array}$ & $\begin{array}{c}4 \\
36.4\end{array}$ & 11 \\
\hline $\begin{array}{l}\text { 整 } \\
\text { 備 }\end{array}$ & $\begin{array}{c}\text { 市街地 } \\
\text { 周辺 }\end{array}$ & $\begin{array}{c}8 \\
50.0\end{array}$ & $\begin{array}{c}6 \\
37.5\end{array}$ & $\begin{array}{c}2 \\
12.5\end{array}$ & 16 & $\begin{array}{c}2 \\
11.8\end{array}$ & $\begin{array}{c}7 \\
41.2\end{array}$ & $\begin{array}{c}8 \\
47.1\end{array}$ & 17 \\
\hline $\begin{array}{l}\text { 課 } \\
\text { 題 }\end{array}$ & $\begin{array}{l}\text { 票村 } \\
\text { 地域 }\end{array}$ & $\begin{array}{c}8 \\
61.5\end{array}$ & $\begin{array}{c}1 \\
7.7\end{array}$ & $\begin{array}{c}4 \\
30.8\end{array}$ & 13 & $\begin{array}{c}7 \\
50.0\end{array}$ & $\begin{array}{c}4 \\
28.6\end{array}$ & $\begin{array}{c}3 \\
21.4\end{array}$ & 14 \\
\hline
\end{tabular}

上段実数、下段（\%)

表-4 市町村の整備課題と対象集落の選定

\begin{tabular}{|c|c|c|c|c|c|c|c|}
\hline & \multicolumn{5}{|c|}{ 対象地区の選定理由 } & \multirow[b]{2}{*}{ 合㖕 } \\
\hline & & $\begin{array}{c}\text { 住民意識 } \\
\text { 高い }\end{array}$ & $\begin{array}{c}\text { 主要施策 } \\
\text { 地区 }\end{array}$ & $\begin{array}{c}\text { 調查の } \\
\text { 結果 }\end{array}$ & $\begin{array}{c}\text { 代表者 } \\
\text { 熱心 }\end{array}$ & \begin{tabular}{|c} 
特殊問題 \\
発生
\end{tabular} & \\
\hline 主 & 既成 & 2 & 3 & 5 & 3 & 5 & 18 \\
\hline 要 & 市街地 & 18.2 & 27.3 & 45.5 & 27.3 & 45.5 & \\
\hline 整 & 市街地 & 2 & 9 & 8 & 3 & 3 & 25 \\
\hline 備 & 周辺 & 11.8 & 52.9 & 47.1 & 17.6 & 17.6 & \\
\hline 課 & 農村 & 5 & 3 & 8 & 5 & 6 & 27 \\
\hline 題 & 地域 & 35.7 & 21.4 & 57.1 & 35.7 & 42.9 & \\
\hline
\end{tabular}

複数回答

上段実数、下段（事例数を母数とした\%）

の性格に対してその必要性が想定し得る生産䂹境整備は、 事例は少ないものの計画は促進されている。中心集落や スプロール集落では、計画策定の必要性や意義を認めら れるような計画目的、例えばスプロール集落における開 発的整備や中心集落における居住噮境整備などについて は、むしろ計画は促進されにくい状況が読み取れる。 以上からフレーム 1 は (1)(2)ともに、市町村の整備課題 や集落地城の性格によって、計画の必要性があるものと 
そうではないものがあり、市町村や集落地域の特性と整 備目的によって計画策定の阻害要因が異なることが明ら かとなった。

\section{6、集落地域における計画条件の錯棕状況}

ここでは、フレーム 2 について検討する。榆討にあた って、錯綜状況を集落地域に含まれる集落の数、集落の 性格の 2 項目によって捉えるものとする。また、それら の錯綜状況を計画の進行状況によって評価し、また、合 意形成・権利調整・整備水淮・協定等の各局面における 困難さを観察することによって、錯綜の内容について考 察する。

錯綜状況と計画の進行状況を比较すると（表一6）、 集落数相6)では複数集落より単一集落方が計画が停漁し ているものが多い。集落の性格ではスプロール集落で進 行しているもの、中心集落や純農村集落で停滞している ものが多い。錯綜の内容を見ると（表－7）、集落数に ついては、両者を比较すると、単一集落では、農家間の 合意形成・権利調整・農業生産関係の協定注7)、複数集 落では、新規宅地規模がそれぞれ困難度が高い。全体的 に単一集落の方が困難度が高く、特に農家がらみあるい は農業がらみの項目についてその傾向が顒著である。一 般的には複数集落の方が錯綜状況は䙓雑と思われるが、 集落の総戸数をみると、単一集落が平均274戸に対して 複数集落の場合の 1 集落当りの平均戸数は 128 戸と半数

表-5 計画策定の必要性（集落）

\begin{tabular}{|c|c|c|c|c|c|}
\hline \multicolumn{2}{|c|}{ 集落性格 } & \multicolumn{2}{|c|}{ 計画目的 } & \multicolumn{2}{|c|}{ 計画の進行 } \\
\hline \multirow[t]{6}{*}{$27^{\circ} 0-\pi$} & \multirow[t]{6}{*}{20} & \multirow[t]{2}{*}{ 生産整㑲 } & \multirow[t]{2}{*}{6} & 進行 & 4 \\
\hline & & & & 停滞 & 2 \\
\hline & & \multirow[t]{2}{*}{ 居住整備 } & \multirow[t]{2}{*}{7} & 進行 & 5 \\
\hline & & & & 停滞 & 2 \\
\hline & & \multirow[t]{2}{*}{ 開発的整備 } & \multirow[t]{2}{*}{7} & 進行 & 3 \\
\hline & & & & 停滞 & 4 \\
\hline \multirow[t]{7}{*}{ 中 心 } & \multirow[t]{7}{*}{9} & \multirow[t]{2}{*}{ 生座整俑 } & \multirow[t]{2}{*}{0} & 進行 & 0 \\
\hline & & & & 停滞 & 0 \\
\hline & & \multirow[t]{2}{*}{ 居住整借 } & \multirow[t]{2}{*}{6} & 進行 & 2 \\
\hline & & & & 停㴆 & 4 \\
\hline & & \multirow{3}{*}{ 開発的整備 } & \multirow[t]{3}{*}{3} & 進行 & 0 \\
\hline & & & & 停滞 & 2 \\
\hline & & & & 欠損 & 1 \\
\hline \multirow[t]{8}{*}{ 純農村 } & \multirow[t]{8}{*}{10} & \multirow[t]{3}{*}{ 生産整徜 } & \multirow[t]{3}{*}{4} & 進行 & 2 \\
\hline & & & & 停滞 & 1 \\
\hline & & & & 欠損 & 1 \\
\hline & & \multirow[t]{2}{*}{ 居住整㒉 } & \multirow[t]{2}{*}{2} & 進行 & 1 \\
\hline & & & & 停帯 & 1 \\
\hline & & \multirow[t]{3}{*}{ 開発的整備 } & \multirow[t]{3}{*}{4} & 進行 & 0 \\
\hline & & & & 停滞 & 3 \\
\hline & & & & 欠損 & 1 \\
\hline
\end{tabular}

以下の規模となっている相8)。大規模な単一集落よりも 複数の小単位で形成されている複数集落の方が、錯綜要 因が少ないものと思われる。集落の性格別に見ると、ス プロール集落では困難度が低い項目が多い。中心集落で は農家間の合意形成や協定において困難度が高く、純農 村集落では農家間の合意形成を除いてスプロール集落や 中心集落に比べて高い困難度を示している。これは中心 集落における農家、純農村集落における非農家といった その集落においてマイナーな存在が阻害要因となりうる ことを示すものと思われる。

以上から、集落地域を構成する集落数および集落の性 格から錯綜状況およびその内容ををある程度、予見可能 であることがわかる。

\section{7、住民㑡・行政㑡での調整機能}

ここではフレーム 3 について検討する。

表 -6 集落における錯綜状況

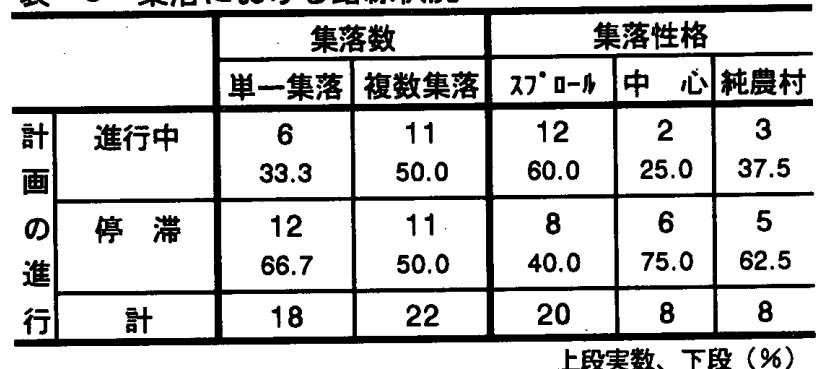

表 -7 集落における錯綜内容

\begin{tabular}{|c|c|c|c|c|c|c|}
\hline & \multicolumn{2}{|c|}{ 集落数 } & \multicolumn{3}{|c|}{ 集落性格 } \\
\hline & & 単一集落 & 複数集落 & $x 7^{\circ} 0-\beta$ & 中 心 & 䣂農村 \\
\hline 合 & $\begin{array}{l}\text { 合意形成 } \\
\text { (農家間) }\end{array}$ & $\begin{array}{c}18 / 21 \\
85.7\end{array}$ & $\begin{array}{c}12 / 21 \\
57.1\end{array}$ & $\begin{array}{c}13 / 20 \\
65\end{array}$ & $\begin{array}{c}8 / 9 \\
88.9\end{array}$ & $\begin{array}{c}6 / 9 \\
66.7 \\
\end{array}$ \\
\hline 意 & $\begin{array}{c}\text { 合意形成 } \\
\text { (非農家間) }\end{array}$ & $\begin{array}{c}13 / 21 \\
61.9\end{array}$ & $\begin{array}{c}12 / 21 \\
57.1 \\
\end{array}$ & $\begin{array}{c}12 / 20 \\
60.0 \\
\end{array}$ & $\begin{array}{c}5 / 9 \\
55.6\end{array}$ & $\begin{array}{l}6 / 9 \\
66.7\end{array}$ \\
\hline 成 & $\begin{array}{c}\text { 合意形成 } \\
\text { (農家,非豊家) }\end{array}$ & $\begin{array}{c}13 / 21 \\
61.9\end{array}$ & $\begin{array}{c}12 / 21 \\
57.1\end{array}$ & $\begin{array}{c}12 / 20 \\
60.0\end{array}$ & $\begin{array}{l}5 / 9 \\
55.6\end{array}$ & $\begin{array}{c}6 / 9 \\
66.7 \\
\end{array}$ \\
\hline $\begin{array}{l}\text { 権 } \\
\text { 利 }\end{array}$ & $\begin{array}{c}\text { 権利的調整 } \\
\text { (既存宅地) }\end{array}$ & $\begin{array}{c}14 / 21 \\
66.7 \\
\end{array}$ & $\begin{array}{c}9 / 19 \\
47.4\end{array}$ & $\begin{array}{c}9 / 18 \\
50.0 \\
\end{array}$ & $\begin{array}{l}4 / 9 \\
44.4 \\
\end{array}$ & $\begin{array}{l}7 / 8 \\
87.5\end{array}$ \\
\hline $\begin{array}{l}\text { 調 } \\
\text { 整 }\end{array}$ & $\begin{array}{l}\text { 権利調整 } \\
\text { (生産基盤) }\end{array}$ & $\begin{array}{c}15 / 21 \\
71.4\end{array}$ & $\begin{array}{c}10 / 20 \\
50.0\end{array}$ & $\begin{array}{c}10 / 19 \\
52.6\end{array}$ & $\begin{array}{l}4 / 9 \\
44.4 \\
\end{array}$ & $\begin{array}{l}7 / 8 \\
87.5\end{array}$ \\
\hline 整 & $\begin{array}{c}\text { 新規宅地 } \\
\text { 配置 }\end{array}$ & $\begin{array}{c}13 / 21 \\
61.9\end{array}$ & $\begin{array}{c}12 / 20 \\
60.0\end{array}$ & $\begin{array}{c}11 / 18 \\
61.1 \\
\end{array}$ & \begin{tabular}{|c|}
$5 / 9$ \\
55.6 \\
\end{tabular} & $\begin{array}{l}6 / 9 \\
66.7 \\
\end{array}$ \\
\hline $\begin{array}{l}\text { 诚 } \\
\text { 水 }\end{array}$ & $\begin{array}{c}\text { 新規宅地 } \\
\text { 規模 }\end{array}$ & $\begin{array}{c}10 / 20 \\
50.0\end{array}$ & $\begin{array}{c}12 / 19 \\
63.2 \\
\end{array}$ & $\begin{array}{c}9 / 17 \\
52.9\end{array}$ & \begin{tabular}{|l}
$5 / 9$ \\
55.6
\end{tabular} & $\begin{array}{l}5 / 8 \\
62.5\end{array}$ \\
\hline 準 & $\begin{array}{c}\text { 道路・施設 } \\
\text { 整備水準 }\end{array}$ & $\begin{array}{c}11 / 21 \\
52.4\end{array}$ & $\begin{array}{c}10 / 20 \\
50.0\end{array}$ & $\begin{array}{c}9 / 19 \\
47.4\end{array}$ & $\begin{array}{l}3 / 9 \\
33.3\end{array}$ & $\begin{array}{c}7 / 8 \\
87.5 \\
\end{array}$ \\
\hline 協 & $\begin{array}{l}\text { 協 定 } \\
\text { (建案) }\end{array}$ & $\begin{array}{c}15 / 21 \\
71.4 \\
\end{array}$ & $\begin{array}{c}13 / 20 \\
65.0 \\
\end{array}$ & $\begin{array}{c}10 / 19 \\
52.6 \\
\end{array}$ & \begin{tabular}{|c|}
$7 / 9$ \\
77.8 \\
\end{tabular} & $\begin{array}{l}8 / 8 \\
100.0 \\
\end{array}$ \\
\hline 定 & $\begin{array}{c}\text { 拹 定 } \\
\text { （農莱農振） }\end{array}$ & $\begin{array}{c}16 / 21 \\
76.2\end{array}$ & $\begin{array}{c}12 / 20 \\
60.0\end{array}$ & $\begin{array}{c}10 / 19 \\
52.6\end{array}$ & $\begin{array}{l}7 / 9 \\
77.8\end{array}$ & $\begin{array}{l}7 / 8 \\
87.5\end{array}$ \\
\hline
\end{tabular}
上段 : 当該項目の困難の度数/当該項目の回答数 下段 : (\%) 
はじめに住民侧での調整機能について考察する。ここで は、調整機能を住民組織の有無姆9)、住民意識の盛り上 りの有無の 2 項目によって捉えるものとする。また、そ れらの調整機能を計画の進行状況によって評価し、合意 形成・権利調整・整備水淛・協定等の各局面における困 難さを観察することによって、調整効果について考察す る。調整機能と計画の進行状況を比較すると（表－8） 、住民組織では、ある場合の方が進行の割合が高い。住 民意識の盛り上がりも、ある場合の方が進行の割合が高 く、これらが計画の促進に関して、何らかの調整機能を 果たしていると考えられる。調整效果の内容を見ると（ 表－9）、住民組織では、住民組織がない場合よりある 場合の方が困難度が相対的に低いものを見ると（10\% 以上差があるもの)，農家間の合意形成・農家と非農家 の合意形成・生産基盤の権利調整・農等生産関係の協定、 といったいずれも農家および農業がらみの項目であり、 非農家間の合意形成や整備水準といった項目については 顥著な効果はみられない。住民意識の盛り上がりのある 集落では、非農家間の合意形成・農家と非農家の合意形 成、といった非農家がらみの項目や協定において、困難 度が低く農家がらみの合意形成や整備水準等については 余り効果がみられない。

以上、2つの項目のどちらも調整の効果の手判かりを 得る指標として有効である。住民組織は主に農家がらみ の調整機能として、住民意識は主に非農家がらみの調整 機能として有効であるが、既存宅地整備・新規宅地整備 ・道路や施設の整備の水準等の新規要素の謂整に関して はどちらも効果が期待できない。

次に行政側での調整機能について考察する。ここでは、 市町村において担当した行政組織を「主として農業関連 の部署が担当」「主として都市計画関連の部署が担当」

「兩担当の分担（等分）あるいは専門の部署が担当」の 3通りに区分し、それぞれについて計画の進行状況や運 営上のトラブル発生状況から調整機能を評価する。また、 集整法に対する認識について比較し調整効果の背景につ いて考察する。

担当した組織別に比較すると（表一－10），「分担 · 専門部署」では明らかに計画は進行しトラブル発生も少 ない。生産環境整備に対する集整法の効果についてみる

\section{表－8 稞落における調整機能}

\begin{tabular}{|c|c|c|c|c|c|}
\hline & \multicolumn{2}{|c|}{ 住民組糡 } & \multicolumn{2}{|c|}{ 住民，意識 } \\
\hline & & 有 & 無 & 有 & 無 \\
\hline $\begin{array}{l}\text { 計 } \\
\text { 画 }\end{array}$ & 進行中 & $\begin{array}{c}10 \\
47.6\end{array}$ & $\begin{array}{c}6 \\
33.3\end{array}$ & $\begin{array}{c}6 \\
66.7\end{array}$ & $\begin{array}{c}11 \\
35.5\end{array}$ \\
\hline $\begin{array}{l}\Phi \\
\text { 進 }\end{array}$ & 停 滞 & $\begin{array}{c}11 \\
52.4 \\
\end{array}$ & $\begin{array}{c}12 \\
66.7\end{array}$ & $\begin{array}{c}3 \\
33.3\end{array}$ & $\begin{array}{c}20 \\
64.5\end{array}$ \\
\hline 行 & 計 & 21 & 18 & 9 & 31 \\
\hline
\end{tabular}

表 -9 集落における調整効果（困難度）

\begin{tabular}{|c|c|c|c|c|c|}
\hline & \multicolumn{2}{|c|}{ 住民組樴 } & \multicolumn{2}{|c|}{ 住民意識 } \\
\hline & & 有 & 無 & 有 & 無 \\
\hline 合 & $\begin{array}{l}\text { 合意形成 } \\
\text { (嵒家間) }\end{array}$ & $\begin{array}{c}14 / 22 \\
63.6\end{array}$ & $\begin{array}{c}16 / 19 \\
84.2\end{array}$ & $\begin{array}{l}6 / 8 \\
75.0\end{array}$ & $\begin{array}{c}24 / 34 \\
70.6\end{array}$ \\
\hline $\begin{array}{l}\text { 意 } \\
\text { 形 }\end{array}$ & $\begin{array}{c}\text { 合意形成 } \\
\text { (非農家間) }\end{array}$ & $\begin{array}{c}12 / 22 \\
54.5\end{array}$ & $\begin{array}{c}12 / 19 \\
63.2\end{array}$ & $\begin{array}{l}4 / 8 \\
50.0\end{array}$ & $\begin{array}{c}21 / 34 \\
61.8\end{array}$ \\
\hline 成 & $\begin{array}{c}\text { 合意形成 } \\
\text { (農家,非農家) }\end{array}$ & $\begin{array}{c}11 / 22 \\
50.0\end{array}$ & $\begin{array}{c}13 / 19 \\
68.4\end{array}$ & $\begin{array}{l}4 / 8 \\
50.0\end{array}$ & $\begin{array}{c}21 / 34 \\
61.8\end{array}$ \\
\hline $\begin{array}{l}\text { 権 } \\
\text { 利 }\end{array}$ & $\begin{array}{c}\text { 梅利調整 } \\
\text { （既存宅地） }\end{array}$ & $\begin{array}{c}13 / 21 \\
61.9\end{array}$ & $\begin{array}{c}9 / 18 \\
50.0\end{array}$ & $\begin{array}{l}4 / 8 \\
50.0\end{array}$ & $\begin{array}{c}19 / 32 \\
59.4\end{array}$ \\
\hline $\begin{array}{l}\text { 調 } \\
\text { 整 }\end{array}$ & $\begin{array}{c}\text { 梅利調整 } \\
\text { （生産基盤） }\end{array}$ & $\begin{array}{c}11 / 21 \\
52.4\end{array}$ & $\begin{array}{c}14 / 19 \\
73.7\end{array}$ & $\begin{array}{l}5 / 8 \\
62.5\end{array}$ & $\begin{array}{c}20 / 33 \\
60.6\end{array}$ \\
\hline 整 & $\begin{array}{c}\text { 新規宅地 } \\
\text { 配置 }\end{array}$ & $\begin{array}{c}15 / 22 \\
68.2 \\
\end{array}$ & $\begin{array}{c}9 / 18 \\
50.0\end{array}$ & $\begin{array}{l}5 / 8 \\
62.5\end{array}$ & $\begin{array}{c}20 / 33 \\
60.6\end{array}$ \\
\hline $\begin{array}{l}\text { 備 } \\
\text { 水 }\end{array}$ & $\begin{array}{c}\text { 新規宅地 } \\
\text { 規模 }\end{array}$ & $\begin{array}{c}13 / 21 \\
61.9\end{array}$ & $\begin{array}{c}9 / 17 \\
52.9\end{array}$ & $\begin{array}{l}5 / 8 \\
62.5\end{array}$ & $\begin{array}{c}17 / 31 \\
54.8\end{array}$ \\
\hline 準 & $\begin{array}{c}\text { 道路・施設 } \\
\text { 整满水準 }\end{array}$ & $\begin{array}{c}11 / 21 \\
52.4\end{array}$ & $\begin{array}{c}9 / 19 \\
47.4\end{array}$ & $\begin{array}{l}4 / 8 \\
50.0\end{array}$ & $\begin{array}{c}17 / 33 \\
51.5\end{array}$ \\
\hline 協 & $\begin{array}{c}\text { 協 定 } \\
\text { (地区計画) }\end{array}$ & $\begin{array}{c}15 / 21 \\
71.4\end{array}$ & $\begin{array}{c}12 / 19 \\
63.2\end{array}$ & $\begin{array}{l}4 / 8 \\
50.0\end{array}$ & $\begin{array}{c}24 / 33 \\
72.7\end{array}$ \\
\hline 定 & $\begin{array}{c}\text { 協 定 } \\
\text { (農業農振) }\end{array}$ & $\begin{array}{c}13 / 21 \\
61.9\end{array}$ & $\begin{array}{c}14 / 19 \\
73.7\end{array}$ & $\begin{array}{l}4 / 8 \\
50.0\end{array}$ & $\begin{array}{c}24 / 33 \\
72.7\end{array}$ \\
\hline
\end{tabular}

上段 : 当賅項目の困難の度数/当賅項目の回答数 下段 : (\%)

表－10 市町村における調整機能と整備方法評価

\begin{tabular}{|c|c|c|c|c|}
\hline & \multicolumn{3}{|c|}{ 主に担当した行政組糡 } \\
\hline & & 豊業関連 & 建設・都市関連 & 分担・専門 \\
\hline \multirow{5}{*}{$\begin{array}{c}\text { 計画の } \\
\text { 進行 }\end{array}$} & 進行中 & 4 & 3 & 10 \\
\hline & & 28.6 & 33.3 & 62.5 \\
\hline & 停 滞 & 10 & 6 & 8 \\
\hline & & 71.4 & 66.7 & 37.5 \\
\hline & 合計 & 14 & 9 & 18 \\
\hline \multirow{5}{*}{ トラブル } & 良 好 & 6 & 3 & 12 \\
\hline & & 40.0 & 37.5 & 75.0 \\
\hline & 問題発生 & 9 & 5 & 4 \\
\hline & & 60.0 & 62.5 & 25.0 \\
\hline & 合計 & 15 & 8 & 16 \\
\hline \multirow{7}{*}{ 農業効果 } & 規制誘導 & 3 & 2 & 1 \\
\hline & 効果 & 15.8 & 10.5 & 25.0 \\
\hline & 事業化 & 13 & 11 & 3 \\
\hline & 期待 & 68.4 & 57.9 & 75.0 \\
\hline & 効果 & 3 & 6 & 0 \\
\hline & なし & 15.8 & 31.6 & 0.0 \\
\hline & 合計 & 19 & 19 & 4 \\
\hline \multirow{7}{*}{ 居住効果 } & 規制誘導 & 8 & 6 & 1 \\
\hline & 効果 & 42.1 & 30.0 & 25.0 \\
\hline & 事業化 & 8 & 11 & 3 \\
\hline & 期待 & 42.1 & 55.0 & 75.0 \\
\hline & 効果 & 3 & 3 & 0 \\
\hline & なし & 15.8 & 15.0 & 0.0 \\
\hline & 合計 & 19 & 20 & 4 \\
\hline
\end{tabular}


と、規制誘導効果・事業化への期待のどちらも、都市関 連の担当よりも農業関連の担当の方が上回り、都市関連 の担当では効果なしと評価するケースも見られる。居住 罣境整備では、規制譑道効果については都市関連の担当 よりも農業関連の担当の方が評価が高く、事業化への期 待については、逆に都市関連の担当の方が高い。また、 分担・専門では、生産環境整備・居住環境整備のいずれ も規制誘導的効果より事業化への期待の方が高い。図一 1 は集整法に関する評価を農業関連担当と都市関連担当 について比較したものであるが、土地利用規制・開発と 保全・法律のわかりにくさと言った両サイドが競合ある いは事業制度の体系が異なるような項目については評価 に差が生じている。

このように、行政レベルでの担当が農亲サイドまたは 都市サイドの一方に偏ると、集整法の評研や認識にもず れが生じ、調整にも問題が発生し計画の進行も阻害され やすい。分担・専門の場合には事業化が極めて高い值を 示す。これは事業化を前提とした場合、両担当の協力体 制が欠かせないことを裏付けているものと思われる。

\section{8、阻害要因の指标的把握}

ここでは阻害要因を計画策定の予見として把暒するこ とを目的として、市町村レベルの「混住化類型」、集落 レペルでの「地娀社会類型」「むら柄」の3つの指標に より、計画プロセスの阻害要因がどの程度、把握できる かについて考察するま进 10$)$ 。以下、各指標の有効性の検 討、各指標を用いた阻害要因の整理の順に述べる。

\section{(1) 3 指標の有好性の検知}

ここで用いている3つの指標は次のように規定してい る。市町村の混住化類型は、文献 8）における混住化類 型において、人口增加率の基準を $5 \%$ としたものを用い ている。地域社会類型は、各集落地域で農家戸数と非農 家戸数によって、農家戸数が多い場合を農家型、非農家 戸数が多い場合を非農家型としている。「むら柄」は行 政担当者の判断によるもので、集落の拘束力と展開性に 関して得た回答のうち展開性（社会集団としての意議の 積極性と住民活動の多様性）に関するものを用いている。 表一 11 は 3 つの指標と計画の進行状況との関俰を示し たものであるが、3つの指標のいずれも計画の進行状況 との間に統計的に有意な関俰が認められる。市町村の混 住化類型では、都市的類型は停滞、Uターン血粶型・農 村団地型は進行中のものが多く、非農家化型はどちらと も言えないといった状況が読み取れる。地域社会類型で は、非農家型に進行中のものが多く農家型に停滞中のも のが多い。「むら柄」では展開性がある集落では進行中 のものが多く展開性がみられない集落では停滞している ものが多い。以上のようにこれら 3 つの指標により、計
画の阻害要因をある程度判断できることがわかる。

(2)湿住化類型による阻害要因の整理

ここでは、混住化類型別に実際に計画策定が行なわれ

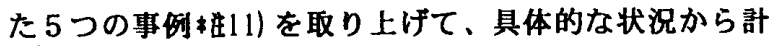
画の必然性について考察し、混住化類型の有効性につい て検討する（表一 12 ）。

農村的類型の事例では、住民側では高い宅地化意向を 反映し計画は進行中であるが、行政レベルでは当該集落 が過㻋地域としての主要施策の对象ではなく、実施末定 の状況である。非農家化型の事例では、町レベル・集落 レベルの何れにおいても人口増はみられず、住民の宅地 化意向も决して高くない。このような状況における計画 としては、その必要性から考えると無理が生じていると 思われる。計画の進行状況を見ても、行政側では実施を 予定しているものの住民侧では盛り上がりに欠けている。 Uターン血粶型の事例では、計画目的および住民意向は、 市レベルでの行政課題に全く一致したものであり、住民 側・行政側共に計画自体の必要性が高いものと考えられ る。また、農村団地型の事例でも集落の計画目的は、農 業とバランスのとれた居住環境整備と新規宅地の若干の 創設としており、町レペルでの行政課題と比㪟的一致し たものとなっている。Uターン血粶型・農村団地型のい ずオも計画の進行状況は、住民侧・行政侧共に実施に向

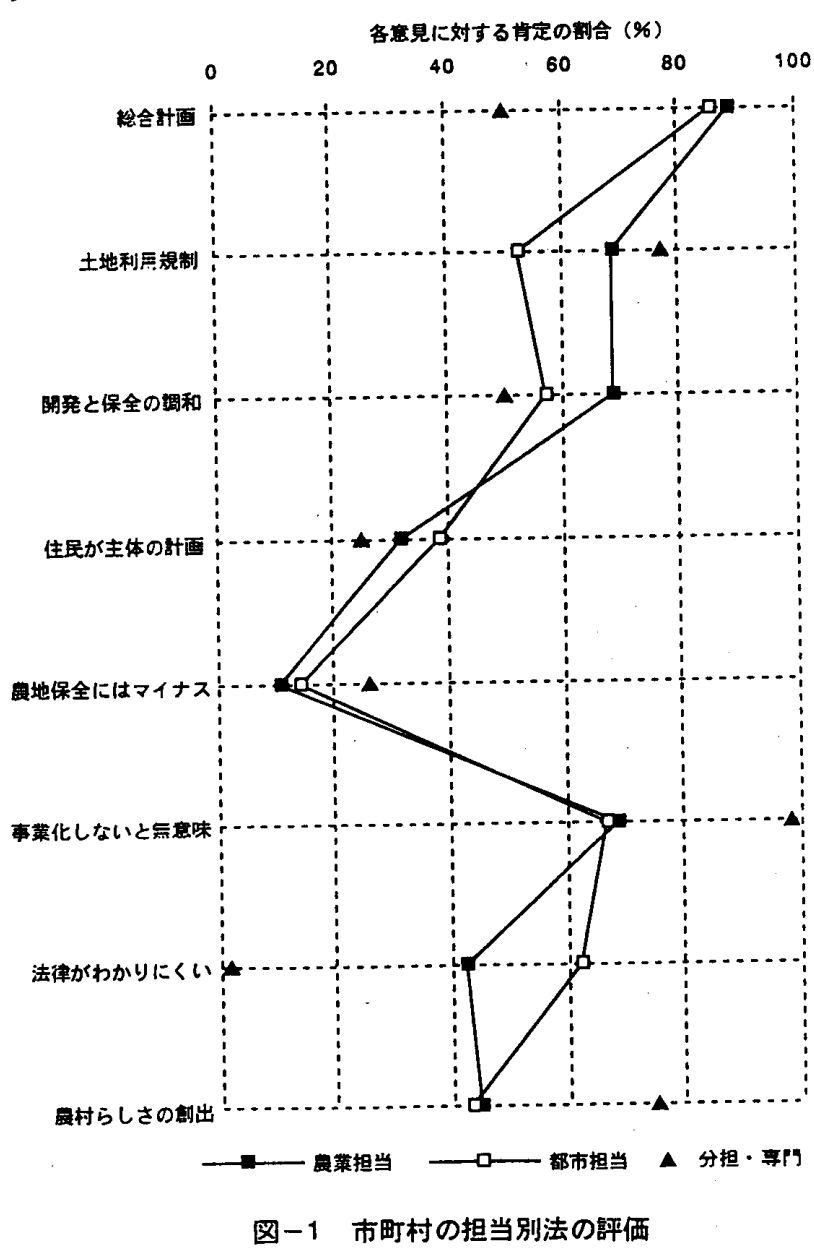


けて動いている。都市的類型の事例では、人口增加もす でに沈静化しており、住民構成も多様化して必ずしも計 画目標の必然性が十分にあるとは言えない。また、行政 側においても、農村的地域の整備は僈先的課題ではなく、 計画の進行状況を見ても、事業のP R 活動は行なわれて
いるが、行政㑡においては事業化は未定の状況で、住民 側でも盛り上がりのかける状況となっている。

以上、5つの事例ではあるが、農村的類型および都市 的類型では行政側における集落地域での計画の位置付け が不明眿であること。非農家化型では新规宅地開発等の

表-11 阻害状況把握のための指標

\begin{tabular}{|c|c|c|c|c|c|c|c|c|c|c|c|}
\hline & \multicolumn{5}{|c|}{ 市町村の混住化類型 } & \multicolumn{2}{|c|}{ 集落地域社会類型 } & \multicolumn{3}{|c|}{ むら柄（展開性） } \\
\hline & & 農 村 & 非豊家化 & Uタ-侐縟 & 農村団地 & 都 市 & 農家型 & 非農家型 & 強 & 中 & 弱 \\
\hline \multirow{2}{*}{$\begin{array}{c}\text { 計画の } \\
\text { 進行 }\end{array}$} & 進行中 & $\begin{array}{c}1 \\
100.0\end{array}$ & $\begin{array}{c}5 \\
50.0\end{array}$ & $\begin{array}{c}3 \\
75.0\end{array}$ & $\begin{array}{c}4 \\
66.7\end{array}$ & $\begin{array}{c}4 \\
21.1\end{array}$ & $\begin{array}{c}5 \\
26.3\end{array}$ & $\begin{array}{c}11 \\
68.8\end{array}$ & $\begin{array}{c}7 \\
70.0\end{array}$ & $\begin{array}{c}5 \\
45.5\end{array}$ & $\begin{array}{c}4 \\
22.2\end{array}$ \\
\hline & 停 滞 & $\begin{array}{c}0 \\
0.0\end{array}$ & $\begin{array}{c}5 \\
50.0\end{array}$ & $\begin{array}{c}1 \\
25.0\end{array}$ & $\begin{array}{c}2 \\
33.3\end{array}$ & $\begin{array}{c}15 \\
78.9\end{array}$ & $\begin{array}{c}14 \\
73.3\end{array}$ & $\begin{array}{c}5 \\
31.3\end{array}$ & $\begin{array}{c}3 \\
30.0\end{array}$ & $\begin{array}{c}6 \\
54.5\end{array}$ & $\begin{array}{c}14 \\
77.8\end{array}$ \\
\hline \multicolumn{2}{|c|}{ 力价乗検定(5\%水準) } & \multicolumn{5}{|c|}{ 有意なし } & \multicolumn{2}{|c|}{ 有意 } & \multicolumn{3}{|c|}{ 有意 } \\
\hline \multicolumn{2}{|c|}{ クラマ-係数 } & \multicolumn{5}{|c|}{0.46} & \multicolumn{2}{|c|}{0.42} & \multicolumn{3}{|c|}{0.40} \\
\hline
\end{tabular}

上段は実数、下段は\%

表-12 事例の分析

\begin{tabular}{|c|c|c|c|c|c|c|c|}
\hline \multirow{2}{*}{\multicolumn{3}{|c|}{ 市町村の混住化類型 }} & 農村的類型 & 非農家化型 & U夕-ン血縟型 & 農村団地型 & 都市的類型 \\
\hline & & & $\begin{array}{l}\text { 新渴県 } \\
\text { SI町 }\end{array}$ & $\begin{array}{c}\text { 秋田県 } \\
\text { Sy町 }\end{array}$ & $\begin{array}{l}\text { 宮城県 } \\
\text { Fu市 }\end{array}$ & $\begin{array}{c}\text { 茨城県 } \\
\text { Hu町 }\end{array}$ & $\begin{array}{l}\text { 千葉県 } \\
\text { Ya市 }\end{array}$ \\
\hline \multirow{7}{*}{ 市町村ル゙ル } & \multirow{4}{*}{$\begin{array}{c}\text { 市町村 } \\
\text { 指標 }\end{array}$} & 스맘 & 2.1 万人 & 0.9 万人 & 6.3万人 & 3.3万人 & 14.7万人 \\
\hline & & 内部非農家率 & $43.9 \%$ & $62.1 \%$ & $57.7 \%$ & $62.6 \%$ & $94.0 \%$ \\
\hline & & 人口増加率(最近 10 年) & $0.7 \%$ & $-3.8 \%$ & $5.8 \%$ & $10.0 \%$ & $4.5 \%$ \\
\hline & & 非農家集団率 & $0.0 \%$ & $0.0 \%$ & $0.0 \%$ & $64.4 \%$ & $48.7 \%$ \\
\hline & \multirow{3}{*}{$\begin{array}{l}\text { 行政 } \\
\text { アソケ-ト }\end{array}$} & 主要整供課題 & 農村整備 & 新市街地形成 & 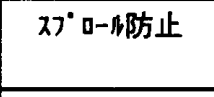 & $\begin{array}{l}\text { 農村整備 } \\
\text { 宅地開発 } \\
\end{array}$ & $\begin{array}{c}\text { 新市街地整備 } \\
27^{\circ} 0-4 \text { 防止 }\end{array}$ \\
\hline & & 行政担当 & 農サイド & 農十都 & 農+都 & 専門 & 豊+都 \\
\hline & & 行政実施予定 & 末定 & 実施予定 & 実施予定 & 実施予定 & 末定 \\
\hline \multirow{14}{*}{ 集落レベル } & \multirow{8}{*}{$\begin{array}{l}\text { 集落 } \\
\text { 指標 }\end{array}$} & 釉戸数(戸) & 104 & 151 & 238 & 450 & 362 \\
\hline & & 人口増加率(最近10年) & $31.6 \%$ & $3 \%$ & $47 \%$ & $5 \%$ & 微增 \\
\hline & & 豊家率 & $41 \%$ & $54 \%$ & $24 \%$ & $43 \%$ & $50 \%$ \\
\hline & & 集落立地 & 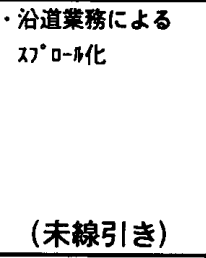 & 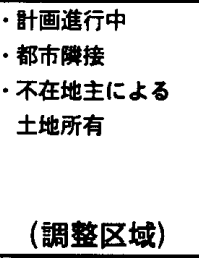 & 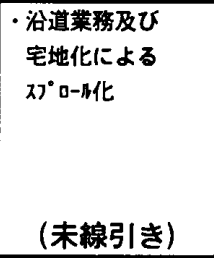 & 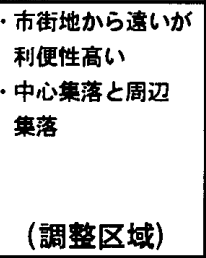 & 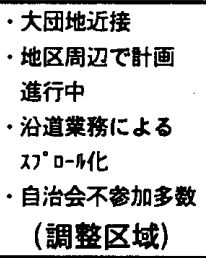 \\
\hline & & 周辺土地利用 & 町中心に近接 & 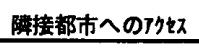 & 市街地近接 & 田園地帯 & 住宅団地 \\
\hline & & 宅地面積(ha)／全面楀(ha) & $\begin{array}{r}23 / 67 \\
(34.3 \%) \\
\end{array}$ & $\begin{array}{c}18 / 201 \\
(9.0 \%) \\
\end{array}$ & $\begin{array}{l}24 / 134 \\
(17.9 \%) \\
\end{array}$ & $\begin{array}{c}26 / 270 \\
(9.6 \%)\end{array}$ & $\begin{array}{l}63 / 243 \\
(25.9 \%)\end{array}$ \\
\hline & & 農地面積(ha) & 39 & 90 & 95 & 223 & 95 \\
\hline & & 農振白地農地面積(ha) & 24 & 28 & 61 & 140 & 55 \\
\hline & \multirow{2}{*}{$\begin{array}{c}\text { 行政 } \\
\text { アソケ-ト }\end{array}$} & 計画目的 & $\begin{array}{c}\text { 農保全 } \\
+ \text { 居住環境改善 } \\
\end{array}$ & $\begin{array}{l}\text { 曹保全 } \\
\text { 足 } \\
\text { 宅地化 } \\
\end{array}$ & $\begin{array}{c}2 フ^{*} 0-n \text { 対策 } \\
+ \\
\text { 宅地化 } \\
\end{array}$ & $\begin{array}{c}\text { 居住環境改善 } \\
\text { 宅地化 } \\
\end{array}$ & $\begin{array}{l}\text { 農保全 } \\
\text { 宅地化 }\end{array}$ \\
\hline & & 策定後の活動状況 & 進行中 & $\begin{array}{c}\text { 登り上がり } \\
\text { に欠ける }\end{array}$ & 進行中 & 進行中 & PR活動中 \\
\hline & \multirow[t]{2}{*}{ 計画案 } & 宅地面積(ha)／全面積(ha) & $\begin{array}{l}23 / 67 \\
(34.3 \%) \\
\end{array}$ & $\begin{array}{l}43 / 201 \\
(21.4 \%) \\
\end{array}$ & $\begin{array}{l}50 / 134 \\
(37.3 \%) \\
\end{array}$ & $\begin{array}{l}36 / 270 \\
(13.3 \%) \\
\end{array}$ & $\begin{array}{l}96 / 243 \\
(39.5 \%)\end{array}$ \\
\hline & & 新規宅地規模(ha) & 5 (白地農地) & 11 & 17 & 10 & 19 \\
\hline & \multirow{2}{*}{$\begin{array}{l}\text { 住民 } \\
\text { 意向 }\end{array}$} & 開発意向（宅地化） & $67.7 \%$ & $44 \%$ & 宝地化指向多数 & $60 \%$ & $53 \%$ \\
\hline & & 農業継続意向 & $79.1 \%$ & $49 \%$ & $89 \%$ & $61 \%$ & $42 \%$ \\
\hline
\end{tabular}


必然性に関して住民側と行政側のずれが生じていること。 Uターン血縁型および農村団地型では、住民・行政の両 サイドとも計画の位置付けが畔み合い、比较的計画の促 進がされやすいこと。等が読み取れ、混住化類型により、 計画の阻害要因を整理できることがわかる。

(3) 地域社会類型及び「むら柄」による阻害要因の整理 ここでは、集落の現状の性格に応じて、地域社会類型 や「むら柄」が、計画の進行を判断する上でどのように 寄与しているのかを検討する。

表一 13 は集落性格別、地域社会類型別に計画の進行 状況を整理したものである。スプロール的集落では、農 家型に比へ非農家型の方が計画が進行している状況が顆 著である。中心集落では、非農家型に進行している例も 見られるものの、農家型・非農家型共に停滞しているも のが多い。純農村的集落で農家型の多くは停滞してお り、非農家型では進行している。同様に、表ー 14 は集 落性格別、「むら柄」区分別に計画の進行状況を整理し たものである。スプロール的集落では、「むら柄」が強 いもの、中間のもの、弱いものがほぼ同数みられ、中程 度あるいは弱いものに比べて、强い場合は計画が促進さ れやすいことが娔み取れる。中心集落では「むら柄」の 強い事例は見られず㐷いものにおいて、計画が停滞しゃ すい状況が読み取れる。純農村的集落では「むら柄」が 強いものと弱いものに分かれ中程度のものは見られず、 強いものに比へて、弱いもので計画が停滞している状況 が読み取れる。

以上から「むら柄」・地域社会類型の 2 指標について は、集落の性格と組み合わせて用いることによって、よ り細かく阻害要因を把握できることがうかがわれる。

\section{9、まとめ}

本論ではサンプル数の限界はあるものの概ね以下の点 が明らかになった。

(1)市町村の整僙訊題や集落地域の性格によって、計画の 必要性が高いものとそうではないものがあり、市町村 や集落地域の特性と整備目的によって計画策定の阻害 要因が異なる。

(2)集落地域を構成する集落数および集落の性格から錯紜 状況およびその内容ををある程度予見することが可能 である。

(3)住民組織は主に農家がらみの調整機能として、住民意 䛨は主に非農家がらみの調整機能として有效である。 行政㑤では、担当が農業または都市の一方に偏ると調 整に問題が発生し計画の進行も阻害されやすい。

(4)混住化類型により、行政侧での計画の阻害要因をある 程度整理することができる。「むら柄」・地域社会類 型の 2 指標については、集落の性格と組み合わせて用 いることによって阻害要因を把握できる。
表-13 地域社会類型別計画進行状況

\begin{tabular}{|c|c|c|c|c|c|}
\hline \multicolumn{2}{|c|}{ 集落性格 } & \multicolumn{2}{|c|}{ 菓落・地域社会類型 } & \multicolumn{2}{|c|}{ 計画の進行 } \\
\hline \multirow[t]{4}{*}{$x 7^{\circ} 0-16$} & \multirow[t]{4}{*}{17} & \multirow[t]{2}{*}{ 農家型 } & \multirow[t]{2}{*}{9} & 進行 & 5 \\
\hline & & & & 停滞 & 4 \\
\hline & & \multirow[t]{2}{*}{ 非農家型 } & \multirow[t]{2}{*}{8} & 進行 & 7 \\
\hline & & & & 停滞 & 1 \\
\hline \multirow[t]{4}{*}{ 中 心 } & \multirow[t]{4}{*}{7} & \multirow[t]{2}{*}{ 農家型 } & \multirow[t]{2}{*}{2} & 進行 & 0 \\
\hline & & & & 停滞 & 2 \\
\hline & & \multirow{2}{*}{ 非農家型 } & \multirow[t]{2}{*}{5} & 進行 & 2 \\
\hline & & & & 停滞 & 3 \\
\hline \multirow[t]{6}{*}{ 䣂農村 } & \multirow[t]{6}{*}{9} & \multirow[t]{3}{*}{ 㤟家型 } & \multirow[t]{3}{*}{6} & 進行 & 0 \\
\hline & & & & 停滞 & 5 \\
\hline & & & & 欠損 & 1 \\
\hline & & \multirow[t]{3}{*}{ 非農家型 } & \multirow[t]{3}{*}{3} & 進行 & 2 \\
\hline & & & & 停滞 & 0 \\
\hline & & & & 久損 & 1 \\
\hline
\end{tabular}

表-14「むら柄」別計画進行状況

\begin{tabular}{|c|c|c|c|c|c|}
\hline \multicolumn{2}{|c|}{ 集落性格 } & \multicolumn{2}{|c|}{ むら柄 } & \multicolumn{2}{|c|}{ 計画の進行 } \\
\hline \multirow[t]{6}{*}{$x 7^{\circ} \square-n$} & \multirow[t]{6}{*}{19} & \multirow[t]{2}{*}{ 強 } & \multirow[t]{2}{*}{6} & 進行 & 5 \\
\hline & & & & 停滞 & 1 \\
\hline & & \multirow[t]{2}{*}{ 中 } & \multirow[t]{2}{*}{6} & 進行 & 3 \\
\hline & & & & 停滞 & 3 \\
\hline & & \multirow[t]{2}{*}{ 弱 } & \multirow[t]{2}{*}{7} & 進行 & 3 \\
\hline & & & & 停滞 & 4 \\
\hline \multirow[t]{7}{*}{ 中 心 } & \multirow[t]{7}{*}{9} & \multirow[t]{2}{*}{ 強 } & \multirow[t]{2}{*}{0} & 進行 & 0 \\
\hline & & & & 停滞 & 0 \\
\hline & & \multirow[t]{2}{*}{ 中 } & \multirow[t]{2}{*}{3} & 進行 & 2 \\
\hline & & & & 停滞 & 1 \\
\hline & & \multirow[t]{3}{*}{ 弱 } & \multirow[t]{3}{*}{6} & 進行 & 0 \\
\hline & & & & 停滞 & 5 \\
\hline & & & & 欠損 & 1 \\
\hline \multirow[t]{8}{*}{ 純農村 } & \multirow[t]{8}{*}{10} & \multirow[t]{3}{*}{ 強 } & \multirow[t]{3}{*}{4} & 進行 & 2 \\
\hline & & & & 停滞 & 1 \\
\hline & & & & 欠損 & 1 \\
\hline & & \multirow[t]{2}{*}{ 中 } & \multirow[t]{2}{*}{0} & 進行 & 0 \\
\hline & & & & 停滞 & 0 \\
\hline & & \multirow[t]{3}{*}{ 弱 } & \multirow[t]{3}{*}{6} & 進行 & 1 \\
\hline & & & & 停滞 & 4 \\
\hline & & & & 欠損 & 1 \\
\hline
\end{tabular}

\section{[謝群]}

本研究の一部は、文部省科学研究費一般研究 B（代表 ・土肥博至）によって実施した。調查にあたっては農水 省構造改善局地域計画課農村整備調查俰の五十嵐氏（当 時）と（財）都市経消研究所の西村氏にご協力をいただ いた。集計にあたっては千葉工大の久武健三君にこ協力 をいただいた。記して感謝申し上げる。 
1) 平成 2 年度時点での数値。

2) 平成 2 年度時点で全国で 67 市町村（1市町村で複数の調查を 行なっているものも含む)で調查が行なわれている。ここでは 特殊な状況にある市町村を除いて調查对象とした。

3）同一集落について2つの担当で計画策定を行なっている場合は イニシアティブをとった担当に依頼し、等分に行なった埸合は 両担当合意のうえの記入を体頼した。

4)ここでは市町村の担当者が各市町村において、集落整储を必要 とする集落を選定し、市町村の中で位置付けを行なうことも重 要な計画プロセスの一部と考えている。

5）表ー3における主要整備課題とは都市部および農村部での地域 政策に関する主要整備課題である。集落の性格とは啟密に規定 された集落類型を示すものではなく、行政担当者に「スプロー ル化のみられる集落」「地区の中心的集落」「純農村的色彩の 強い集落」の判定を委ねたものである。計画目的とは農業生産 境境の整備が主目的の場合を「生産整借」、既存集落の居住瑔 境整储が主目的の場合を「居住整備」としている。開発的整備 とは新規宅地開発の整借を主目的とした計画を意味している。 いずれも必ずしも集整法の主旨に添った䦳き方をしたものでは なく、地城の実状を捉えることを主目的としたものである。

6) ここでの集落とは、集整法で規定される集落地域に含まれる集 落を意味する。

7）ここでの協定とは、協定を結ぶことについての合意に関して調 查したものである。

8)この值はアンケートの戸数を集計したものである。戸数の差は、 集整法による採択の目安として集落地域の総戸数を規定してい る（1５０戸程度）ことが影稫しているものと考えられる。

9) アンケートでは、住民組織については自治会組織で集落整借の 組織の機能を兼ねているものと、新规に自治会組織とは別の組 織ができている場合に分けて䦎いている。さらに後者について は、自主的に組織ができたものと䝘場の指導によってできたも のを分けて聞いている。新規の組織ができたものは殆どなく、 ここでは前者に限って集計している。

10）混住化類型は、内部非農家率・非農家集団率・人口增加率によ り、市町村自の混住化現象を類型化したものである。農村的色 彩の強い類型（農村的類型）、従来の農家が非農家に転化した 類型（非農家化型）、Uターン等による個別的な来住非農家の 割合が高い類型（Uターン血緑型）、農村地域でありながら住 宅団地などによる集団的な新住民の割合が高い類型（農村団地 型）、内部非農家率が高く既成市衔地に多く見られる類型（都 市的類型）の類型からなる。地域社会類型は、集落の住民構成 により類型化したもの。「むら柄」は、集落の社会的体質を分 類したものである。

11） 5 市町の農菜集落計画報告書、田園居住区整備計画報告書、お よび各市町の行政アンケートの個票を資料としている。いずれ の事例も集整法 3 条の 5 要件を满たしていると考えられる。

\section{考文献}

1）三国政勝、中村攻、藤本信義 : 農村地域整偖の手法について、 1990 年 日本建築学会学術講演梗概集

2）三国政勝、中村政 : 集落地城整偳の課題と方法 2、1992年 日本建築学会学街諢演梗概集

3）糸長浩司、青木志郎、東正則 : 集落活性化のための集落整備計 画の㮆討、1990年 日本建筮学会学術講演梗概集

4) 川伢雅章 : 集落土地利用計画と農家の農地利用意向に関する研 究、1993 年 日本建栄学会学術講演梗概集

5）弥吉元媇、加藤仁美、古賀制幸 : 久山町における集落地域整借 法の適用事例、1993年 日本建築学会学術講演梗概集

6）日本建築学会集落地域整備基本方針策定倜查特別委員会：千葉 県集落地域整備基本方針（案）策定調查報告書、1990

7）秋山隆史 : 集落地域整備にかかわる計画の現状と課題（第 1 回 集落地域整備推進セミナー）、（財）都市絓济研究所／(財) 農村開発企画委員会、1991
8）鎌田元弘 : 大都市周辺地域の混住化類型とその計画的課題に関 する考察、日本建策学会計画系論文報告集 No.375, pp104 113, 1987.5

9）鎌田元弘、土肥博至 : 集落の類型化による混住化の通合性の評 価、日本建策学会計画系論文報告集 No. 420, pp 49 56. 1991.2

10）鉡田元弘、士肥博至 : 混住化の受け入れ側の桦件としての「む ら柄」の检討、日本建築学会計画系論文報告集 No.407, D D 119 $\sim 128,1990,1$

（1994年12月10日原稿受理，1995年 9 月14日採用決定） 